3. Ларин А. Н. К проблеме саморегуляции в процессе физической подготовки курсантов военных институтов войск национальной гвардии Российской Федерации. / А. Н. Ларин, А. В. Дубровский, В. П. Чердынцев // Журнал «Современные проблемы науки и образования». - 2016, № 6. URL: https://www.science-education.ru/ru/article/view?id=25794.

4. Ларин А. Н. Моделирование саморегуляции поведения как средства повышения результативности физической подготовки курсантов военных институтов войск национальной гвардии Российской Федерации. / А. Н. Ларин, А. В. Дубровский // Мир образования - образование в мире.- 2017. -№1 (65). С 210-216.

5. О роли двигательной активности студентов гуманитарных вузов и способах ее повышения / А. А. Горелов [и др.] // Ученые записки университета им. П.Ф. Лесгаф- та. - 2009. - № 1 (47). - С. 28-33.

6. Подлипняк, Ю.Ф. Педагогические основы системы физической подготовки слушателей вузов МВД СССР :дис. ... д-ра пед. наук / Подплиняк Ю.Ф. - М., 1986. - 430 с.

7. Слепов В.А. Новая педагогика» в образовательных организациях войск национальной гвардии российской федерации // Вестник Санкт-Петербургского Университета МВД России.-2016.

\title{
Лопсан-Ендан Ч.М. \\ Методика подготовки учащихся к ЕГЭ с помощью тестовых заданий с рисунками
}

Тувинский государственный университет (Россия, Кызылл)

doi:10.18411/spc-22-10-2017-13

idsp: 000001:spc-22-10-2017-13

Один из способов достижения личностных, метапредметных и предметных результатов, запланированных ФГОСсреднего (полного) общего образования, проведение уроков учета, контроля знаний и умений, в ходе которых учащиеся соотносят теоретические знания и с их практическим применением, логически размышляют, сами делают выводы [5].

В связи с этим на учителя возлагаются очень ответственные задачи, главная из которых заключается в том, что именно на уроке учащемуся должны быть представлены все необходимые условия, которые обеспечили бы ему должное развитие. Каждый этап урока должен включать не просто необходимый набор содержания, удовлетворяющий целям и задачам урока, а набор приемов, методов, дидактических средств, способствующих активизации мыслительной деятельности, стимулирующих постоянное развитие учащихся. Таким образом, современному учителю важно уметь грамотно организовать учебный процесс, в котором основным методом и средством обучения становится химический эксперимент, именно он помогает в решении основных метапредметных и предметных результатов обучения [1].

Химико-педагогическое образование предполагает формирование у школьников отчетливых представлений о тесной связи между теоретическими знаниями и практическими умениями. С этой целью можно предложить учащимся тестовые задания с рисунками, в условиях которых описаны конкретные химические операции (действия), отражающие физические и химические свойства веществ. При решении учащиеся с помощью рисунков анализируют, осмысливают и объясняют, выбирают способы решения, а результатом служит осознание их личностной значимости: школьники видят пользу химического эксперимента на теоретическое знание.

На основании исследований $[2,3,4]$ нами разработаны тестовые задания с рисунками и составлены по аналогии с контрольно-измерительными материалами ЕГЭ. Каждый из вариантов состоит из двух частей. Задания части 1 предполагают задания на множественный выбор, установления соответствия и последовательности действий. Задания части 2 требуют подробного ответа на вопрос.

Цель предлагаемой методики помочь учащимся осознать сущность химического эксперимента и научить ориентироваться в свойствах веществ.Данная методика включает в себя два этапа: проведение химического эксперимента и тестирование. В тестировании предлагаем задания с рисунками о действиях и операциях, связанных с 
веществами. Часть 2 содержит проблемный вопрос и направлен на углубление и расширение знаний по химии.

Рассмотрим примеры тестовых заданий с рисунками, которые могут быть использованы в подготовке к выполнению заданий ЕГЭ по химии.

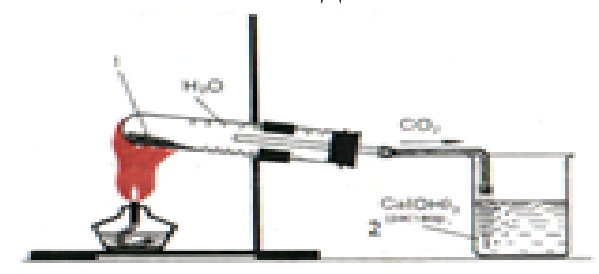
ответов.

Пример 1. Тестовые задания с рисунками с выбором нескольких правильных

При разложении основного карбоната меди (малахита) образуется

а) вода;б) кислород;в) оксид меди;г) углекислый газ

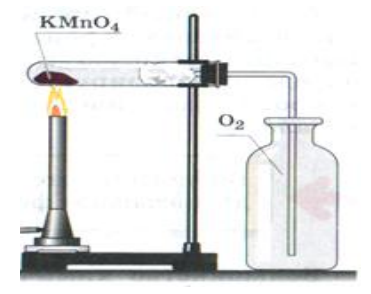

Ответ: а,в,г.

Пример 2. Задания с развернутым ответом.

На основании приведенного опыта напишите уравнение химических реакций, используя метод электронного баланса. Укажите окислитель и восстановитель.

Пример 3. Тестовые задания с рисунками на установление соответствия.

Установите соответствие между названиями опытов и иллюстрациями

\begin{tabular}{|l|l|}
\hline Название опытов & 1. Проверка наличие газа кислорода \\
\hline 2. Проверка наличие газа водорода & 3. Проверка прибора на герметичность \\
\hline &
\end{tabular}

Ответ: 1в, 2г,3а

Основное преимущество тестовых заданий с рисунками - малая вероятность, а часто невозможность угадать ответ без предварительного выполнения химического эксперимента. Тестовые задания с рисунками позволяют самостоятельно обнаруживать пробелы в структуре своих знаний, практических умений и принимать меры для их ликвидации только после выполнения или отработки химического эксперимента, 
систематизировать и обобщить знания по химии, что положительно сказывается на итоговой аттестации.

$$
\text { *** }
$$

1. Киселева Е.В. Использование элементов развивающих технологий в химическом практикуме / Химия в школе. № 6. 2014 . С. 61. -65.

2. Куулар, Л. Л. Тестовые задания с иллюстрациями как компонент тестов // Науч. тр. ТувГУ. Кызыл: Изд-во Тувин. гос. ун-та. .2013. .Выпуск 11.С.4-5.

3. Куулар Л.Л., Качалова Г.С.Иллюстрации как компонент тестовых заданий /Современные проблемы науки и образования. 2016. № 3; URL: http://www.scienceeducation.ru/article/view?id=24693 (дата обращения: 07.06.2016).

4. Куулар Л.Л. Тестовые задания с рисунками как средство оценивания качества результатов обучения и уровня сформированности профессиональных компетенций / Вестник ТувГУ. Педагогические науки. Выпуск 4. 2016. С.173 - 181.

5. Федеральный государственный образовательный стандарт среднего (полного) общего образования, утвержденный приказом Министерства образованияи науки Российской Федерацииот «17» апреля 2012 г. № 413. 